\title{
Accountability and Reform in the Aftermath of the Westray Mine Explosion
}

Eric M. Tucker

Osgoode Hall Law School of York University, etucker@osgoode.yorku.ca

Source Publication:

Working Disasters: The Politics of Recognitions and Response. New York: Baywood, 2006.

Follow this and additional works at: https://digitalcommons.osgoode.yorku.ca/scholarly_works

\section{Recommended Citation}

Tucker, Eric M. "Accountability and Reform in the Aftermath of the Westray Mine Explosion." Tucker, Eric, ed. Working Disasters: The Politics of Recognitions and Response. New York: Baywood, 2006. p. 277-309. ISBN: 9780895033192 


\title{
CHAPTER 10
}

\section{Accountability and Reform in the Aftermath of the Westray Mine Explosion}

\author{
Eric Tucker
}

\section{DEATH IN THE DOMINION}

The Westray mine exploded on May 9, 1992 killing all 26 miners who were working underground at the time. It quickly became apparent that the explosion was not an unforeseeable accident, but rather the predictable result of unsafe and unlawful mining practices, and lax regulatory enforcement. Inadequate ventilation allowed methane concentrations to reach explosive levels and coal dust had been permitted to accumulate. A spark, most probably from an underground mining machine striking a rock, ignited the gas, growing into a rolling methane flame that in turn ignited the coal dust, causing a coal-dust explosion. The mine inspectors knew of these hazardous conditions. During the summer of 1991, without making a formal order, they demanded that the company produce a stone-dusting plan to address the coal-dust hazard. By March 1992 nothing had been done. At that time the inspectors first became aware of dangerous levels of methane, but nothing was done. The next inspection took place on April 29, 1992. Finding that the coal dust problem still had not been addressed, the inspector finally issued a formal order requiring the company to clean up the hazard immediately and to produce a coal-dusting plan by mid-May. Ten days later, the mine exploded (Glasbeek and Tucker 1993; Jobb 1994; Richard 1997).

Within a short time of the explosion, the victims' families, trade unionists, and others began demanding accountability and reform. They wanted to know who was responsible for creating the hazardous conditions in the mine and why they had been allowed to persist. This demand for accountability was not just directed at individuals, but also at organizations and systems. Numerous institutions of redress were mobilized: an inquiry was established; criminal charges were laid against Curragh Inc. (the legal owner of the mine) and two of its on-site managers; 
workers' compensation payments were made to the surviving families; damage actions were brought by the families of the dead miners; and campaigns were conducted to change the law. Yet, more than 10 years later, no individual or organization has been held criminally or civilly liable for the deaths of the miners and the occupational health and safety (OHS) regime has changed little. In 2003, however, the criminal law was amended by the so-called "Westray Bill," which purports to make the prosecution of health and safety crimes easier. In short, it seems that while legal accountability was evaded, and the reform-inducing producing potential of this disaster was partially blunted, the specter of egregious criminality going unpunished for apparently technical reasons so threatened the legitimacy of the law that legislators eventually felt compelled to respond. This chapter seeks to explain how this happened.

It begins with a model that identifies some key factors that influence responses to disasters. The model is then applied to the Westray aftermath, examining in greater detail the prosecution of criminal charges, compensation to the victims' families, the inquiry's recommendations in regard to the OHS regime, and regulatory and legislative changes. The final section draws some brief conclusions.

\section{DETERMINANTS OF THE PUBLIC OUTCOMES OF OHS DISASTERS: A WORKING MODEL}

While there is now a large body of literature that explores the causes of disasters, much less attention has been paid to the study of their effects on public policy. This chapter proceeds from the assumption that once an event has come to be socially constructed as a work disaster (see earlier chapters) it has a potentially disruptive social effect; it may generate demands that individuals and organizations, typically celebrated for their entrepreneurial finesse and lauded for their contribution to the economic well-being of society, be branded as wrong-doers or criminals for the harm their wealth-producing activities have caused. As well, such events may make visible and call into question, in a dramatic and public way, the acceptability of the existing OHS regime and the criminal laws that apply to corporate misconduct in the workplace. Thus, there is a need to inquire into the factors that influence whether and to what extent work disasters will be crisis producing in the above senses.

It is also necessary, however, to explore the factors that influence the state's ability to manage these crisis tendencies. How and to what extent are state institutions and actors able to contain political harm and reassure the public that the government is not giving employers and corporations special treatment? How and to what extent can those who demand redress effect a de-legitimation of existing institutional arrangements and their underlying assumptions and social relations, and obtain redress? Figure 1 depicts a model for studying both these sets of OHS disaster outcome determinants. 


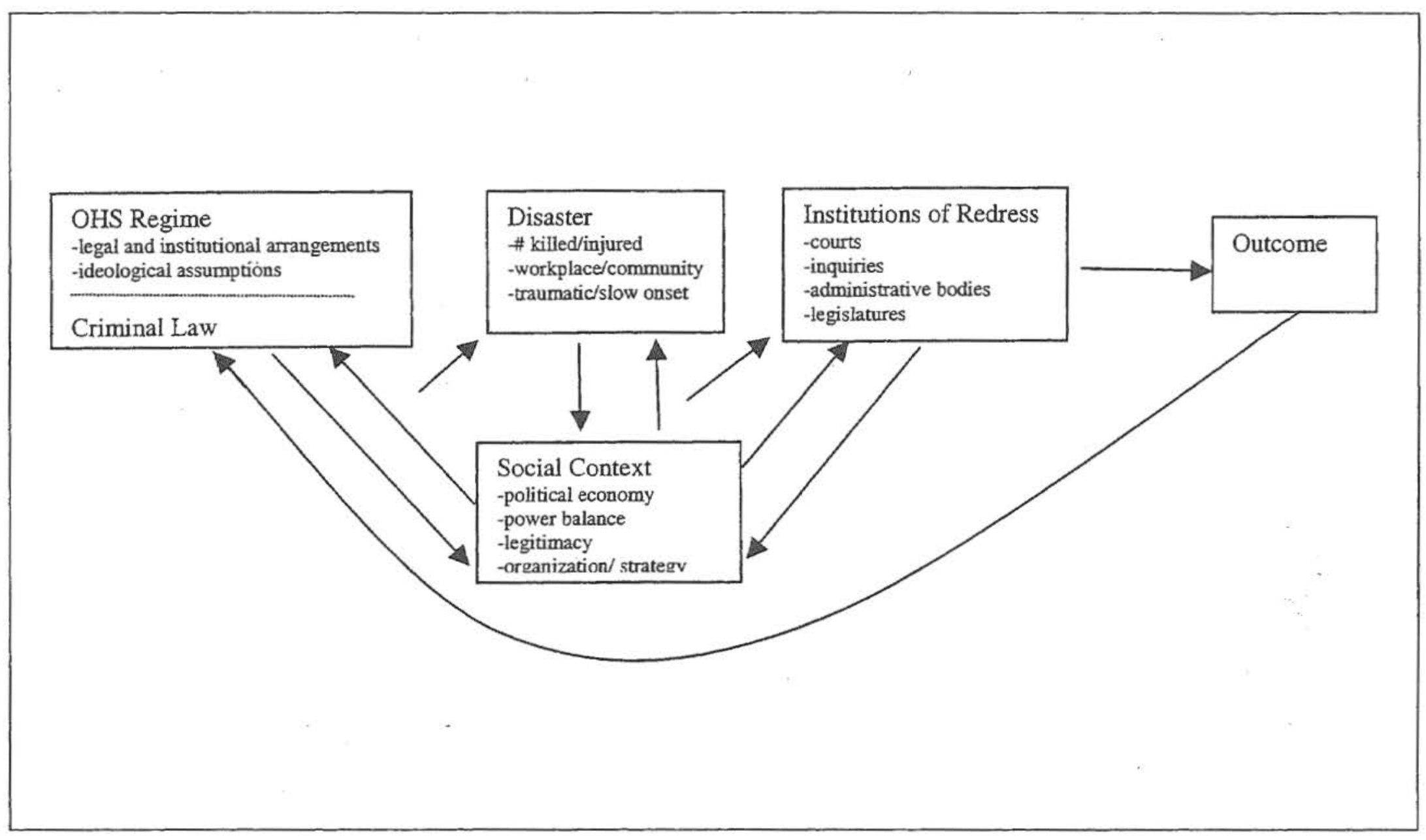

Figure 1. Determinants of the public outcomes of a working disaster. 
The starting point is the pre-disaster OHS/criminal law regime and the broader social context in which it operates. The OHS regime most obviously includes the laws that directly regulate the work environment and the institutional arrangements for their implementation and enforcement. Workers' compensation systems are also part of this regime because they almost invariably aim to influence OHS outcomes, either through education and promotion programs or through their funding mechanisms (e.g., experience-rated premiums or penalty assessments). In some jurisdictions, tort law also forms part of the OHS regime insofar as the threat of litigation influences the behavior of employers and workers. In addition to legal and institutional arrangements, I have also included as part of the OHS regime the dominant ideological assumptions that shape regulatory decision-making and behavior. These include the beliefs of regulatory officials about the causes of hazardous working conditions, the compatibility or worker and employer interests, and social relations of production. The criminal law has been partially hived off from the OHS regime because it is not typically construed as part of it. This is because the behavior that results in worker deaths and injuries is not viewed with the same seriousness as analogous wrongdoing committed outside the workplace. Of course, this is a purely ideological construction, but one with a long historical lineage (Tucker 1990, pp. 66-75). It is, however, currently being challenged.

The model presupposes that OHS regimes do not operate apart from or independently of the social context in which they are located, and are shaped by and, to a lesser extent, shape that context. The work of Paul Shrivastava (1987) on Bhopal is relevant here for its insistence that technological and organizational systems must be located in their broader social context in order to appreciate both their risks and the possibility of averting future industrial crises. Here, too, the relation between the OHS regime and its social context is vital to our model because it permits a better understanding of why the regime operated in the manner that it did prior to the disaster and of the regime's vulnerability to de-legitimation in the disaster's aftermath. It is hypothesized that when an OHS regime enjoys near hegemonic status or faces opponents who are poorly positioned to challenge it, the crisis potential of disasters is less likely to materialize in significant and effective pressure for change.

The next locus of inquiry is the characteristics of disaster itself, including the number of workers killed or injured, whether the harm is confined to the workplace or spreads to members of the broader community, and its time frame (e.g., a traumatic event inflicting immediate harm as opposed to the slow onset of harm from long-term exposures or the accumulation of single instances of harm). These characteristics, however, are only meaningful because they are imbued with significance through social and institutional processes and must be understood in the broader social context in which they occur. For example, to the extent that workplace deaths have been naturalized, even when they involve single incidents that kill many workers at once, the crisis-producing potential of the 
incident-which may not even be socially construed as a disaster-will be diminished. But it is also hypothesized in this model that there is an interactive relationship between the disaster and the social, context, such that a disaster may produce shifts in the balance of power, alter perceptions of the legitimacy of the existing regimes of regulation or governance, and generate different organizational and strategic responses. These interactions will vitally influence the impact of the disaster on the institutional mechanisms for redress (including legislatures, courts, commissions of inquiry, administrative agencies, and legislatures). This is because the identification of objectives and the ability of social actors to achieve them will depend on a variety of social forces and processes. The work of Renn (1992) using the social arena metaphor is helpful here. Renn argues that to be successful groups must mobilize social resources, including money, power, social influence, value commitment, and evidence. His emphasis on the scope for political action and the plurality of social resources helps avoid reductionist tendencies present in more structural accounts of policy processes. However, while Renn recognizes that resources are unequally distributed and that arenas operate under certain constraints, his focus on environmental harms and their more broadly dispersed effects, in conjunction with a generally liberalpluralist perspective, leaves untheorized the structural basis for unequal resource distribution or the nature of the constraints operating within policy arenas. These lacunae in Renn's approach become major omissions in the context of OHS where class and class conflict are often central. Therefore, a political economy approach will be used to deepen the analysis of the operation of social arenas (Nichols 1999; Pearce and Tombs 1999).

From this perspective, it is absolutely essential to recognize that the overwhelming majority of the immediate victims and their families are working-class. Writers such as Michael Reich (1991) have demonstrated that, in the aftermath of disaster, victims and their families are drawn out of their private worlds and become involved "in another world of problems, conflicts identities and institutions" as they seek redress (Reich 1994, p. 181). They will frequently form associations to represent and advance their common interests before the institutions of redress. Often, they will be joined and supported by trade unions, especially when the victims were trade-union members themselves. However, the goals of victims' groups and trade unions may not be identical, as the former may be more immediately concerned with individual and organization accountability for the deaths and compensation while the latter may be more strongly focused on system accountability and reform of the OHS regime to better protect health and safety in the future. In the aftermath of a disaster, both groups are likely to be better positioned than at other times to mobilize political and ideological resources that will shift the balance of power in favor of redress and regime reform.

It is important, however, to recognize that working-class actors are likely to face significant opposition unless their demands stay within narrow and accepted 
channels. The disaster-employer in particular and employer organizations in general also can be expected to mobilize. They will do so to defend themselves against legal liabilities, adverse ideological and political effects, and unwanted legal and institutional changes. However, in the immediate aftermath of a disaster, their ability to mobilize social resources may be weakened, especially if there is prima facie evidence that the disaster-employer's failure to meet its legal obligations to its victim-workers was an operative cause of the disaster. Notwithstanding such disruptions of normal politics, we must keep in mind that any resulting power re-balancing will take place within a larger political economy that is unlikely to have been fundamentally altered by the disaster. The structural power imbalances between labor and capital will still be operative and exert a continuing influence over efforts to re-negotiate the OHS health and safety regime and its underlying assumptions.

Disaster politics are often conducted in a number of distinct institutional settings or policy arenas, each of which has its own particular possibilities and constraints. Criminal trials, civil actions, administrative decision-making, public inquiries, and legislatures use different procedures and are bound by different decision-making rules. For example, the rules of evidence and those defining the burden of proof are different in criminal trials than in tort actions and public inquiries. These systems also place different limits on the chains of causality that can be pursued. As well, some social resources are formally permitted to operate in some institutions but not others. For instance - at least in theory - the outcome of a criminal trial is not to be influenced by money or social influence, but only by evidence of a certain kind. Judges are meant to be neutral and a number of formal safeguards are in place to immunize them from outside influences. Decision-making is to be guided by prescribed rules. In contrast, decisions of legislatures are formally open to lobbying, petitions, and other kinds of political influence.

Lastly, the model's analysis must be attentive to the different forms of redress that actors might be seeking and that institutional processes can produce. Thus, it will often be the case that efforts are being made to seek compensation, punish the offenders, and reform the OHS regime, all at the same time. Not only are some of these goals more achievable than others, but we must also be cognizant of the formal and informal interactions between these goals and the institutions invoked to achieve them. While it is not necessarily the case that the pursuit of one goal comes at the expense of another, we cannot ignore the fact that actors have finite amounts of energy and resources and, for a variety of legal reasons, efforts in one arena may limit those in others. However, it may also be the case that the outcome in one arena may influence outcomes in others and, in particular, that the failure to hold individuals and organizations accountable for egregious wrongdoing may reinforce demands for legal reforms that address the accountability gap. 


\section{REDRESS IN THE AFTERMATH OF THE WESTRAY DISASTER}

\section{The Pre-Disaster OHS Regime and Its Social Context}

Nova Scotia, like all other Canadian jurisdictions, adopted an OHS regime of mandated partial self-regulation (Rees 1988; Tucker 1995a). An essential characteristic of this regime is that it requires employers and employees to self-manage their health and safety according to certain legally prescribed processes and standards (the so-called internal responsibility system or IRS) while also maintaining a system of direct state regulation (the so called external responsibility system or ERS). In Canada, the IRS provides a role for worker participation through the right to know, the right to participate in mandatory bipartite local health and safety committees, and the right to refuse unsafe work. The ERS imposes duties on employers and employees through statutes and regulations that are enforceable by inspectors and through prosecutions.

Within these broad parameters, mandated partial self-regulation can assume many different forms. Two crucial variables are the strength of worker participation rights and the balance between internal and external responsibility systems. The Nova Scotia variant, adopted in 1985 , took a particularly restrictive approach to the right to refuse. It provided that workers could not refuse because of dangers that were "inherent" in the job and that work refusals could not continue after a unanimous joint committee had determined that the work was safe or labor department officials had advised the employee to return to work. Confusion about the right to be paid during a work refusal further reduced the willingness of workers to exercise it (Nova Scotia 1985). ${ }^{1}$ The external responsibility system in Nova Scotia was also a weak one. Neither old mine safety statutes, nor industrial and construction safety regulations were updated. In addition, the maximum fine under the Act was on the low end of the spectrum $(\$ 10,000)$. More importantly, the government adopted an enforcement policy that depended almost exclusively on persuasion. Between 1985 and 1990, a total of 14 prosecutions were undertaken for violations of health and safety laws and the largest fine imposed was $\$ 2,500$. Not a single mining company was prosecuted, notwithstanding the fact that 1037 formal directives were issued to mine operators to correct violations of health and safety laws between 1987-88 and 1991-92 (Glasbeek and Tucker 1993, p. 25).

The weak powers granted to workers in the IRS and the lacks of enforcement in the ERS are justified on the assumption that employers and workers have a common interest in respect of OHS. It is posited that, to employers, "reasonable" safety pays and that "reasonable" employees should be satisfied with that level of safety. As a result, social relations between employers and workers should be cooperative and the parties should be able to self-regulate without significant 
external intervention. The emergence of conflict is constructed as a sign of deviance, either on the part of an employer who fails to understand that the expected level of safety pays, or on the part of employees who are irrational in their demands for safety or who may be using OHS to achieve other (e.g., collective bargaining) objectives.

These institutional arrangements and ideological assumptions are rooted in a local political economy that is best characterized by its underdevelopment (Brym and Sacouman 1979). The Nova Scotia economy has been heavily dependent on the export of staples into volatile and increasingly unfavorable world markets. As a result, governments have been particularly anxious to attract would-be investors to provide much needed jobs. Moreover, these conditions have adversely affected the Nova Scotia labor movement, which has gone from being one of the strongest and most militant in the country to being much less effective and influential (Earle 1989). As a result, organized labor in Nova Scotia has not been particularly aggressive on OHS issues and has not challenged the assumptions and practices embedded in the regime. As well, the Conservative Party had dominated provincial politics, holding office continuously from 1956 to 1993 , leaving the labor movement with little political leverage.

These conditions set the stage for the Westray mine disaster. Not only were the developers of the mine able to extract very sizeable government loan guarantees and favorable contract commitments to purchase its coal, but during the approval process their mining plans were not scrutinized by officials to determine if they could be executed safely. The top priority of politicians was to secure funding for and approval of the project, and regulatory officials implicitly understood these priorities. The mine developer's main concern was coal production, but it continually encountered setbacks in meeting its goals. As a result, pressure was placed on local managers to get the coal out, fostering a culture of risk-taking and a cavalier attitude toward safety (Cooke 2003). Regulatory officials responsible for monitoring mine safety and adherence to approved plans consistently failed to ensure that detected breaches of regulatory requirements were rectified (Glasbeek and Tucker 1993; Jobb 1994; Richard 1997). As hazardous conditions became manifest, experienced miners quit when they saw that their concerns were not going to be addressed by management and that the inspectors were not going to take effective action to force the company to operate safely. The growing fears of the remaining inexperienced and nonunionized Westray miners remained "private trouble" (Comish 1993; Mills 1959 , p. 8)-until it was too late.

\section{Mobilizing the Institutions of Redress}

In the immediate aftermath of the explosion on May 9, 1992 it was not known whether there were any survivors. As rescue teams rushed into action, intensive 
media attention focused on the unfolding drama. Although from the outset, the company devised a media strategy that aimed to deflect blame from itself, it could not contain the flow of information about the miners' prior expressions of concern, the issuance of orders by the mine inspectors, and the failure of the company to comply with those orders (Richards 1998). As it became clear that no miners survived and that human agency rather than ineluctable natural forces caused the explosion, there was widespread questioning of the efficacy and legitimacy of the existing regime of $\mathrm{OHS}$ regulation and a demand that responsible individuals and institutions be held to account. And so a multitude of institutions of redress were mobilized in response to demands for accountability and reform. One of the immediate influences of the disaster on the balance of social forces was that it gave rise to a new and important voice: the victims' families. Many of them formed the Westray Families Group to pursue their demands for justice. In so doing, they were drawn out of their private worlds into the public sphere, taking on an unfamiliar and uncomfortable role that they felt compelled to assume if only to vindicate the reputations of their loved ones against suggestions that the men were responsible for what had happened (Dodd 1998, 2001). The labor movement, particularly the United Steelworkers of America (USWA), which was in the midst of an organizing drive at the Westray mine at the time of the explosion, ${ }^{2}$ also assumed an active role in demanding redress.

Against this background, Donald Cameron, the Conservative Premier of the province at the time, promised a public inquiry. Within days after the suspension of the rescue effort, Cameron appointed Mr. Justice Richard to head up an inquiry under the Public Inquiries Act and the Coal Mine Regulation Act. The provincial auditor commissioned a private consultant (Coopers Lybrand) to conduct a review of management practices at the Department of Labor, and the Nova Scotia Occupational Health and Safety Advisory Council, representing both labor and management, was commissioned to review the Occupational Health and Safety Act $(O H S A)$ and its regulations and to make recommendations for reform. A police investigation was commenced as well and the Royal Canadian Mounted Police (RCMP) took control of the mine site 12 days after the explosion. That fall, charges were laid against the employer under the provincial OHSA but were subsequently dropped in April 1993 after the employer (Curragh Corporation) and two local managers, Gerald Philips and Roger Parry, were charged with manslaughter and criminal negligence causing death. The entitlement of the surviving family members under the province's workers' compensation law was never in question and so that aspect of compensation was handled routinely and without much controversy. Workers' compensation, however, is a no-fault system, so no findings of blame or responsibility were made. The level of compensation is set by legislation, and it neither fully reimburses victims and their families for their economic loss, nor awards punitive or other non-economic damages. As a result, the surviving families launched a civil action against Curragh, its board of directors, Clifford Frame (Curragh's chief executive officer), 
the manufacturers of machinery used in the mine, and the governments of Nova Scotia and Canada.

It is beyond the scope of this chapter to provide a detailed account of the conduct and fate of each mechanism of redress (Jobb 1999; Tucker 1995b). Rather, the focus here is on the broader question of their outcome and the social and institutional forces that shaped these results. Although it is somewhat artificial to draw a sharp line between accountability and reform, since mechanisms for holding individuals and organizations accountable (e.g., the civil and criminal law) may also be seen to have systemic effects on the OHS regime, and since some responses, like inquiries combine these functions (often uneasily), it is nevertheless useful for our purposes to draw this distinction.

\section{Accountability}

Partial Compensation, but No Fault-A prominent demand of victims in the aftermath of a disaster is that they be compensated for their losses, both economic (e.g., lost income) and non-economic (e.g., pain and suffering). Redress of this sort is typically obtained through the workers' compensation and/or the tort system. ${ }^{3}$ Victims may also look to the tort system as a means of holding individuals and organizations publicly accountable for their actions because the court must determine that there was intentional or negligent conduct before it can award damages. Some also believe that the tort system can promote systemic change by deterring potential wrongdoers who will wish to avoid being named and blamed, and to pay damages to the victims. This section examines the ability of the Westray families to mobilize these systems and achieve their objectives of obtaining compensation, holding individuals and organizations accountable for their wrongdoing, and deterring such behavior in the future. Their experience will be related to broader debates about the responsiveness of these institutions to workers' concerns in the aftermath of a disaster and their potential effectiveness as an element of the OHS regime.

Workers' compensation in most Canadian jurisdictions compensates surviving family members for their economic losses reasonably well. Compensation is payable without the need to prove that death was the fault of the employer and, where the work-relatedness of the death is obvious as in the Westray case, administrative officials make entitlement determinations quickly so that compensation payments start shortly after the loss occurs. Payment is made out of a state-administered insurance fund paid for by employer premiums. Payment is secure, even in the face of large claims in the aftermath of disaster, and lawyers are rarely involved in the claims process, so none of the compensation payments are lost to legal costs.

Under Nova Scotia law as it stood at the time of the Westray explosion, widows were entitled to a life pension calculated at $75 \%$ of pre-accident gross earnings up to a maximum of $\$ 36,000$. Because the percentage is based on gross 
rather than net earnings, the widows' pension will replace nearly all of the lost income, provided the deceased worker made no more than the maximum. In the case of the Westray miners, most were earning more than the maximum, and as a result the widows are not being fully compensated for the loss of their partners' income. However, these benefits are indexed to ensure that they keep pace with the cost of living and the level of the pension will increase as the maximum earnings cut-off is increased in the future. Survivors also get an additional monthly payment for each child that continues until age 18 or, if the child remains in school, to 25 . In addition, the families of the deceased miners received a lump sum death benefit of $\$ 15,000$ and $\$ 4,000$ for funeral expenses. A spokesperson for the NS workers' compensation board estimated that it would pay out $\$ 15$ million in benefits, but that this could increase to $\$ 25$ or $\$ 26$ million, depending on inflation and future increases to the maximum pension level (COHSN, 8 Feb. 1993).

Although the workers' compensation did not fully replace the families' economic losses, its performance in response to the Westray disaster did not attract significant criticism, ${ }^{4}$ despite the widespread discontent of Nova Scotia workers with the system's treatment of workers with permanent disabilities and appeal backlogs. Indeed, neither the Westray families nor the labor movement mobilized in pursuit of legislative or administrative reforms in response to the Board's handling of the Westray claims. ${ }^{5}$ These groups also recognized, and implicitly accepted, that the design of the system does not provide for assignment of blame or the award of exemplary damages, that it pays very little compensation for noneconomic losses, and that it has little deterrent effect. ${ }^{6}$

Because of these limitations, disaster victims often find the tort system attractive, as did a number of Westray families. They commenced a $\$ 30$ million damage action against the employer (Curragh Corporation), out-of-province manufacturers of equipment used at the mine, the Governments of Canada and Nova Scotia, and the mines' inspectors. However, this lawsuit faced a formidable legal barrier. In Nova Scotia and other Canadian jurisdictions, workers' compensation laws severely limit the right of injured workers and their survivors to sue. The statutory bar precludes actions against the worker's employer and any other employer covered by the province's workers' compensation legislation. It also forecloses actions against employees of covered employers.

The action against Curragh was subsequently dropped, both because it stood no chance of being allowed to go ahead and because Curragh was bankrupt. The lawsuit against out-of-province equipment manufacturers was also dropped, not because it was barred by statute, but because the families were advised that it would take years to resolve and would be very costly to pursue (Bell $v$. Canada (Attorney General) 2001). This left the governments of Nova Scotia and Canada as defendants.

In 1998, following the report of the Westray Inquiry, the Westray families initiated settlement talks with the Nova Scotia government, lowering their damage claim $\$ 12.6$ million. After much delay, the government announced in December of 
that year that it would not offer an out-of-court settlement. This was consistent with its position that it did not accept legal liability for the disaster. The government subsequently moved to have the action against it dismissed on the grounds that it was an employer under the statute and, therefore, protected by the statutory bar.

The status of the government as a protected employer under workers' compensation statutes had recently been before the Supreme Court of Canada in Pasiechnyk v. Saskatchewan (Workers' Compensation Board) (1997) where the court held that it was reasonable for the WCB to conclude that the government was protected by the statutory bar, notwithstanding that it was being sued in its capacity as regulator and not employer. While this left open the possibility that different conclusions might be reached by workers' compensation boards in other jurisdictions, the court's holding undoubtedly strengthened the Nova Scotia government's position that the statutory bar protected it.

In dismissing the families' action, Mr. Justice Davison began his analysis with a quote from the dissenting judgment of Justice L'Heureux-Dubé in Pasiechnyk:

The tragic factual circumstances that have led to these proceedings are irrelevant to the ... legal question at issue. (1997, p. 920)

Having established the requisite emotional distance, Davison J. then dryly parsed the applicable statutory language and rules of interpretation, concluding that the government is an employer for the purpose of the statute and is thus protected against tort claims by injured employees. The effect of this judgment also precluded an action against the provincial inspectors, because the bar also protects employees of covered employers from civil liability. The Nova Scotia Court of Appeal upheld Davison J.'s judgment and the Supreme Court of Canada denied leave to appeal. Although the families vowed to fight on (Brooks 2002), they have no real prospect of advancing their suit and so it is extremely unlikely that tort litigation will help achieve their goals of obtaining a formal assignment of blame and additional compensation, or deterring future employers and governments from creating and/or tolerating unsafe working conditions.

Clearly, even in the face of what a court might characterize as gross negligence by the employer and the mines inspectors, the victims were unable to convince the government that it should voluntarily pay additional compensation or to persuade the judiciary to open the door to tort litigation. Moreover, they were unable to mobilize broader support for their demands, so that neither the government nor the court (nor for that matter, the law it was interpreting) has faced much criticism, suggesting that in Canada, unlike the United States, civil actions against employers and governments are not widely viewed as an avenue of redress that victims of workplace disasters should be entitled to pursue. ${ }^{7}$

Given this outcome, the Westray experience adds little to debates over the tort system's efficacy in delivering the kinds of redress that it is, at least in principle, institutionally capable of providing to disaster victims. However, a few 
brief comments are still in order. ${ }^{8}$ First, the goals of denunciation, compensation, and deterrence are only advanced if the appropriate defendant is found to be at fault. Although the onus of proof is on the plaintiff, unlike in a criminal proceeding, it is enough to prove liability on a balance of probabilities. As well, corporate defendants will be held vicariously responsible for the negligent acts of their officers and employees. Finally, the discovery process assists the plaintiff in getting information from the defendant. Still, plaintiffs face serious hurdles, including the fact that, in the first instance, they bear the cost of gathering and presenting the evidence. Moreover, well-off or well-insured defendants who have a significant stake in the litigation will take advantage of the tort system to delay proceedings and increase the plaintiff's costs. In short, there are significant obstacles to holding individuals and organizations accountable through the tort system.

Second, it is not clear that success in litigation would produce more compensation for victims. The workers' compensation board would have been subrogated to the action and entitled to reimbursement for its expenses out of the proceeds. Thus, the plaintiffs would only be better off to the extent that the tort damages exceeded the workers' compensation award and, according to one recent assessment, that outcome is unlikely (Hyatt and Law 2000, pp. 338-351).

Third, the deterrent effect of tort is premised on the desire of potential torfeasors to avoid the shame attached to civil blame, as well as its financial cost. How strong are these effects? If the case is successful, a finding against the defendant is one that attaches blame and, while it does not have the same significance as a guilty verdict in a criminal trial, it can still cause embarrassment, especially when the court finds there has been reckless disregard for human life in the pursuit of profit. However, just as in a criminal trial, it is likely that the case will be presented in such a way as to emphasize the deviance of the defendants, rather than the systemic nature of hazardous working conditions (see Johnstone, ch. 8 this volume). So, contrary to the claims of Bale (1989), successful tort actions are unlikely to undermine the legitimacy of the systems that encourage the creation of hazardous work environments. Moreover, because the defendant is most likely a corporation, individual officers and managers will escape personal blame.

Perhaps even more than shame, the deterrent effect of the tort system rests on its supposed ability to impose significant financial costs on wrongdoers, thus creating an incentive for persons engaging in potentially hazardous activities to take greater care to avoid causing harm to others. The empirical support for this hypothesis, however, is thin. First, as Ison argued, the tort system is a "forensic lottery" that delivers compensation to only a fraction of those who have valid claims (Ison 1967). Second, although exemplary and punitive damages are becoming more common in Canada, they are still rare and usually modest (Feldthusen 2000, Whiten v. Pilot Insurance 2002), and damages for pain and suffering have been capped. Third, most defendants are likely to be insured, so that they will probably not have to bear directly the cost of the damage award 
(Atiyah 1997). Fourth, even if the award exceeds the insurance coverage, defendants facing large damage awards have developed an array of strategies, including bankruptcy protection, to reduce their financial exposure.

In sum, if the Westray families had been able to sue successfully for damages, they would have gained whatever satisfaction comes from having a formal determination of fault made by a court. However, it is unlikely that they would have been that much further ahead financially or that the deterrent effect of a successful lawsuit would have been very significant (Dewees, Duff, and Trebilcock 1996, ch. 6). It is even less likely that the litigation would have challenged the underlying ideological assumptions and institutional arrangements that contribute to the problem of unhealthy and unsafe work.

Crime Without Punishment-Criminal prosecutions are first and foremost a way of holding individuals and, to a lesser extent, organizations such as corporations accountable. The choice of wrongs that are deemed to be of such a serious nature that they warrant criminal sanctions as opposed to private remedies through civil actions is a deeply political and ideological one. Historically, the criminal law has not been applied against employers whose actions have caused death and injury to their workers. In part, this is because employment relations are viewed as a realm of voluntarism in which workers assume some risk of injury in exchange for wages. Because this consensus view informs much of contemporary OHS regulation, it has been argued that the use of criminal sanctions against employers becomes a means of challenging the conventional wisdom and promoting system reform (Glasbeek 1988).

The Westray criminal prosecutions were a legal disaster from start to finish (Jobb 1999). The Nova Scotia government initially refused to assign a full-time crown attorney to the case, despite a plea from the RCMP to do so. The two prosecutors finally appointed in September 1992, three-and-a-half months after the disaster, complained that they were not provided with the most basic resources needed to do their job properly, leading them to resign in February 1993. This contributed to a slip-up whereby the prosecution failed to obtain a court order needed to retain evidence seized from Curragh pursuant to a search warrant. In response to an application from Curragh's lawyers, the prosecution was given one month to lay charges or hand over the evidence. So, on April 20, 1993, the RCMP announced that Curragh Corporation and two of its onsite managers, Gerald Phillips and Roger Parry, were being charged with manslaughter and criminal negligence causing death. However, those charges were subsequently quashed in July 1993 by a provincial judge who found them too vaguely worded $R v$. Curragh Inc. 1993). New charges were filed shortly thereafter and these survived legal challenge $R v$. Curragh Inc. 1994).

By then, a new legal team had been put in charge of the prosecution and had been given a budget to enable it to manage the mass of evidence that was involved in this complex case. The trial began in February 1995. The defense repeatedly 
claimed that it had not been given adequate disclosure of Crown evidence as required by Canadian law. The case was dragging ahead slowly when the presiding judge, Robert Anderson, phoned the head of the prosecution service to demand the removal of the lead prosecutor. The Crown demanded a mistrial but was refused by Justice Anderson. The Crown secured an emergency hearing before the Supreme Court of Canada on April 5 but this Court determined that it had no jurisdiction to intervene in the midst of a trial (R. v. Curragh Inc. 1995a). The trial resumed before Justice Anderson and continued until June, when he granted a defense motion to stay the charges because of the failure of the Crown to disclose key evidence about methane sensors and coal dust samples $(R$. v. Curragh Inc. 1995b).

The Crown appealed Anderson's ruling to the Nova Scotia Court of Appeal. In its judgment, issued in December 1995, the court ruled that Anderson's behavior gave rise to a reasonable apprehension of bias and ordered a new trial (R. v. Curragh Inc. 1995c). A new prosecution team was assigned to the case and given additional resources, much of which were devoted to cataloguing the mass of documents in the Crown's possession in order to avoid future disclosure problems. The defense challenged the Court of Appeal's decision before the Supreme Court of Canada. Its judgment was issued in March 1997. A 7-2 majority upheld the Court of Appeal's order for a new trial, agreeing that the trial judge's conduct had created an apprehension of bias $(R, v$. Curragh Inc. 1997). The majority did not comment directly on the Crown's failure to disclose, but it did order the Crown to pay the defendants' reasonable legal costs. ${ }^{9}$

The Director of Public Prosecutions in Nova Scotia, however, was losing his enthusiasm for a case that was already absorbing a significant portion of his office's budget and that threatened to become even more costly. Moreover, by then the commission of inquiry (see infra., p. 295) had issued its report which attributed the explosion to a persistent pattern of disregard for basic mine safety and a breakdown of regulatory systems. Guilt was pervasive. Following the commission's report, one of the prosecutors, Jack Hagell was asked to prepare a report assessing the strength of the Crown's case. His recommendation, given in October 1997, was that the charges be withdrawn because it would be "fundamentally unfair" to prosecute only Phillips and Parry when many others, including miners, foremen, and government inspectors, shared responsibility for the explosion. Hagell was also critical of the investigation and the early handling of the case. While Hagell withdrew from further involvement with the case, his colleagues labored on. A further internal assessment estimated that the prosecution would cost in the vicinity of $\$ 10$ million, that there was no consensus on the likelihood of conviction, and that a jail sentence was unlikely even if there was a conviction (McCormick 1999b, p. 21). In July 1998 the Nova Scotia Justice Minister announced that the criminal charges were being stayed and would not be revived. A prosecution could not be pursued under provincial OHS laws either because 
the Crown had previously stayed charges in order to clear the way for the criminal prosecution.

While the immediate causes of the failure of the Westray prosecution were a combination of incompetence and lack of political and fiscal support for the effort, it would be wrong to assume that successful criminal prosecutions are usual in the aftermath of a health and safety disaster in Canada or elsewhere (Hopkins 1989; Slapper 1999). For example, in twentieth century Canada, research to date has uncovered only 10 instances in which employers were charged with criminal offences in relation to dangerous working conditions, and only one conviction that withstood appeal (Law Reform Commission of Canada 1986; Tucker 1995b). In 1943, Brazeau Collieries Ltd. was convicted of criminal negligence after 29 coal miners died in a methane gas explosion. Chief Justice Ives imposed a fine of $\$ 5,000$. He justified this small penalty because of the "close and friendly association between mine officials and miners" (Calgary Herald 19 January 1943; Rex v. Brazeau Mines 1942).

Why has the criminal law been so marginal to OHS regulation and why is it so hard for it to be deployed as mechanism to denounce and punish employer wrongdoing in the aftermath of a disaster?

There are at least two levels of explanation for criminal law's separation from the OHS regime: the sociological and the legal-institutional. According to many radical criminologists, the criminal law does not stand in an external relation to society, but rather is a product of and an instrument for maintaining unequal social relations. As a result, there has been enormous resistance in capitalist societies to categorizing wrongdoing by the economically powerful as criminal activity (Chambliss and Seidman 1971; Pearce 1976; Pearce and Tombs 1999; Slapper 1993; Taylor, Walton, and Young 1973). Resistance is particularly high when it is alleged that an employer has committed a crime in the course of profitmaking workplace activity. This is because of the underlying assumptions that employment relations are consensual and that employees accept some level of risk. This, after all, is one of the justifications for the IRS. A criminal charge represents a social judgment about the unacceptability of certain risks and does not permit individual consent to them. As such, its use in the employment context is anomalous.

This closure, however, is never complete in liberal societies that also embrace the ideal of equality before the law and some commitment, however thin, to minimum standards of social welfare for all citizens. So while the deep-seated assumption that capitalist production gone wrong is to be treated differently than analogous behavior occurring in other contexts that are not similarly valued is rarely questioned during normal times, workplace and other disasters often produce a popular demand for justice that, in the Anglo-American context, is increasingly fulfilled through the prosecution and punishment of wrongdoers under the criminal law (Wells 1995, ch. 7). ${ }^{10}$ This was certainly the case in the aftermath of the Westray disaster. Although trade unions and the Westray Families Group took the lead in making this demand, they gained popular support as 
knowledge of the employer's reckless behavior became widespread through media reports. Thus, the very act of charging an employer or its agents with a criminal offense challenges the normative order, throwing into question assumptions about common interests between workers and employers and challenging the legitimacy of profit-maximizing behavior (Glasbeek 1984).

The symbolic importance of criminalizing employer misconduct, however, virtually ensures that attempts to do this will encounter institutional resistance and that powerful actors will mobilize to limit the threat. This points toward the second level of explanation that focuses on legal and institutional impediments to successful prosecutions of corporate/capital crime. The large body of literature on this subject can only be touched upon lightly here. One problem that commentators have identified is that of assigning criminal responsibility to individuals who act within a corporate structure that is designed to shield individuals from legal liability. Connecting high-level corporate officers and directors to the crime can be a difficult task in an organization in which responsibility is diffuse and in which operational decisions are taken by lower-level officials in the corporate hierarchy (Tombs 1995). Collecting evidence from the boardroom and weaving together a coherent and compelling story for the jury that will implicate senior corporate actors is likely to be such a time-consuming and daunting task that police and prosecutors are hesitant to proceed. Of course, it is also possible to prosecute the lower-level corporate officials, such as the on-site managers, for their personal wrongdoing (as was done in the case of Westray), but this may be resisted by prosecutors and judges who feel that it is unfair to let the small fry take the blame when the big fish have gotten away.

It is often assumed that it is easier to prosecute the corporation itself rather than particular corporate officials. This has been facilitated by developments in the criminal law that, for example, allow corporations to be prosecuted for mens rea offenses such as manslaughter. However, the complexity of such cases still is great. According to the headnote in the leading Ontario case on the subject, "[a] corporation is responsible for the criminal acts of its servant only if the servant has authority, express or implied to do the act, or if the servant is virtually its directing mind in the sphere of duty assigned to him so that his actions and intent are the very actions and intent of the corporation itself, provided that in performing the acts in question the agent was acting within the scope of his authority, either express or implied" (R. v. McNamara et al. (No. 1) 1981). However, as in the case of prosecuting individuals, the cost and difficulty of gathering evidence necessary to prove all elements of the offense beyond a reasonable doubt is likely to be great. Corporations and senior company officials have the resources to mount a vigorous defense, ensuring that their rights are scrupulously respected and using the complexity of the corporate organization to undermine the prosecution's case. This means that the prosecution will have to be prepared to devote considerable resources to the case, often when it is operating under fiscal restraints. Resource allocation decisions are also likely to be influenced by underlying attitudes 
about the appropriateness of prosecuting corporate actors in the first place, by direct political considerations, and by doubts about whether the game is worth the candle when a conviction will be difficult to obtain and, if the corporation is the accused, there is literally no body to punish (Benson 2001; Coffee 1981; Geis \& DiMento 1995; Slapper 1999). Often, as in the case of Curragh, the corporation will have ceased to exist or other creditors will have seized its assets, making any fine impossible to collect.

Finally, the theory of criminal liability in these cases is likely to be that the employer behaved in a reckless manner. To increase the probability of success, the prosecution is likely to adopt a strategy of decontextualization and individualization. Rather than emphasizing the broader context that promotes the behavior in question, or drawing attention to the frequency of unlawful employer conduct, both the prosecution and the media will tend to focus on the particular facts of the case and to characterize corporate defendants as bad apples in what is a generally good barrel (Johnstone, ch. 8 this volume; McMullan and Hinze 1998). Thus, even in those rare cases where the popular demand for justice overcomes the deeply ingrained resistance to seeing respectable members of the employing classes condemned as pariahs for their undisciplined pursuit of profits resulting in death and destruction, there is a danger that a conviction will be interpreted as an affirmation, rather than a critique, of the normative order.

So while the problems encountered in the Westray prosecution initially look idiosyncratic, upon closer examination the failure of the criminal prosecution in that case appears typical of the criminal law's response to corporate/capital wrongdoing. The public outcry in the immediate aftermath of the disaster pushed a reluctant government to pursue a criminal investigation and to file charges, but the initial failure to provide the necessary resources resulted in legal missteps that nearly saw the charges dismissed and produced substantial delay. By the time those problems were resolved-nearly five years after the explosion-a differently constituted government, under marginally less public pressure, was not prepared to commit substantial resources to a prosecution whose outcome was uncertain and that targeted two low-level managers of a now bankrupt corporate employer. This failure of accountability produced a demand for criminal law reform, which will be examined in the next section of the chapter.

\section{Reform}

Public Inquiry: Naming, Blaming, and Recommending More of the SameInherent in criminal trials and tort actions is a focus on the actions of particular defendants. Thus, any broader impact of a successful prosecution or law suit will be indirect, either by contributing to a shift in the way people view health and safety in the workplace, or through general deterrence. Public inquiries, however, usually have a broader mandate. While they too search for accountability, they 
make no legal determinations of wrongdoing. Rather, they typically look for systemic problems and make recommendations aimed at preventing their recurrence. Because of their different mandate, inquiries are not conducted according the rules that govern trials: they are not restricted by rules of evidence; participation in the proceedings is relatively open; and it is not up to those who are seeking particular recommendations to prove its factual predicate on a balance of probabilities. For these reasons, public inquiries can be an important institution through which to raise issues of organizational and social accountability for events, and to influence the public thinking and the future direction of state policy (Roach 1995).

Almost inevitably, inquiries of one sort or another are established in the aftermath of a mining death, so there is little difficulty in activating this institution of redress. Legal impediments, however, still may arise. There has been recent concern that provincial inquiries aimed at alleged wrongdoing of specific individuals are invalid because they are tantamount to criminal proceedings, a matter within federal jurisdiction. As well, the power of inquiries to compel individuals to testify has been challenged in respect of persons facing criminal charges on the ground that it would violate their right to remain silent. Both of these issues were raised in respect of the Westray inquiry. Ultimately, the Nova Scotia Court of Appeal upheld the authority of the province to call the inquiry on the ground that its dominant purpose was to make findings in respect of a coal-mine disaster rather than to investigate whether a criminal offence had been committed (Phillips v. Nova Scotia (Commission of Inquiry) 1993), and the Supreme Court of Canada upheld the right of the commissioner to compel testimony from persons facing criminal charges because of the importance of the public interest at stake and because they were protected against having that testimony or derivative evidence used in a subsequent trial (Phillips v. Nova Scotia (Commission of Inquiry) 1995). This litigation delayed the start of the inquiry's public proceedings until November 1995, three-and-a-half years after it was established. Although the inquiry ultimately did not hear from senior Curragh officials and Phillips or Parry, the two local officials still facing criminal charges at the time, ${ }^{11} 71$ witnesses testified in 76 days of well-publicized hearings, including the former Premier, the mine inspectors, former Westray miners, and families of the deceased miners. It also received numerous written submissions, including ones from the Westray families, the USW, and other labor organizations.

Its report, released in November 1997, was scathing in its criticism of the operators of the Westray mine and of the government for failing to properly regulate and stop their dangerous and unlawful mining practices. In respect of Curragh, the commission found that "it created a workplace that fostered a disregard for worker safety. ... [M]anagement's drive for production, together with its disdain for safety, played a key role in the devastation of the Westray mine" (Richard 1997, p. 135). The commission's condemnation of the government's failures started at the top with Donald Cameron, the premier at the 
time, who in his testimony had blamed the miners for the explosion. Cameron's explanation was characterized as "self-serving, cynical and simplistic" (1997, p. 222) and his aggressive pursuit of the project was seen to have sent a signal to the bureaucracy that Westray was to be given special treatment. The departments of Natural Resources and Labor, which had direct oversight of the mining, were both found to be derelict in meeting their statutory responsibilities. The commission made 73 recommendations to the Nova Scotia government, which accepted them all within days of the inquiry's report (Nova Scotia 1997).

The Westray families, trade unions, and the media welcomed the report's findings (e.g., Halifax Daily News 7 December 1997). For the families, the exoneration of the men from blame in their own deaths and the condemnation of Curragh and Cameron was particularly satisfying (Dodd 2001), while the unions, particularly the USW, were pleased with the recommendations to increase corporate accountability (King 1998). However, despite its angry condemnation of employer misbehavior and government inaction, the report failed to confront many of the underlying structural conditions and ideological assumptions that make the production of unsafe conditions and government non-enforcement so common (Tucker 1999).

Almost totally missing from the report was any discussion of the relation between safety and profit. Of course, the pursuit of both safety and profits is not necessarily inconsistent: safe production methods will sometimes enhance profitability. But the potential for conflict is always there, especially in a situation where those immediately responsible for production are under pressure to show a profit in the short run. Instead of addressing this problem, the report makes it magically disappear:

Once a mine is open, there begins the process of trade-off between production and safety. From the chief executive officer to the miner at the working face, the objective must be to operate the mine in a manner that ensures the personal safety of the worker over the economic imperatives of increased production. The two seemingly competing concepts - safety and production-must be so harmonized that they can co-exist without doing harm to each other. (Richard 1997, p. viii)

But how are they to co-exist? The answer is given on the next page. The Westray management "through either incompetence or ignorance, lost sight of the basic tenet of coal mining: the safe mining of coal is good business" (Richard 1997, p. ix). So, after all, there is no need for a trade off. But if safe production is always good business, then, given the tragic history of coal mining disasters and the high frequency of work-related death and disease in the industry, one is at a loss to explain why mine operators have tended to be such ignorant or incompetent business people.

This understanding of the production of OHS hazards contributes to the report's faulty analysis of the failure of the government inspectors to enforce the 
law. Richard claimed that it was an erroneous understanding of the IRS that "was a major deterrent to effective enforcement of the safety regulations" (Richard 1997, p. 455). The error lay in ascribing to inspectors the role of being persuaders and facilitators whose mandate was to promote the capacity of the workplace parties to assume primary responsibility for OHS in the workplace. The problem with this analysis, however, is that Richard failed to recognize that this approach to enforcement is not a corruption of the IRS model but rather is a manifestation of its ordinary operation. Even in Ontario, which has the most OHS prosecutions in Canada, the emphasis is on the promotion of self-reliance and inspectors almost never launch a prosecution until after a worker has been killed or seriously injured as a result of a violation of OHS laws and regulations. The reason for taking this approach is the core belief that workers and employers share a common interest in OHS and therefore should, with a little gentle persuasion and advice from the inspector, be able to self-regulate. Thus, despite Richard's denunciation of the failure to enforce in this particular case, the report embraces a model wherein the very behavior he criticizes is the norm. It is telling that Richard makes no specific recommendation in his report that the inspectors should use their coercive powers more frequently against employers who are found to be in violation of the law. Instead, the Inquiry recommended that an independent consultant should be retained to evaluate the inspectorate and its personnel (Richard 1997, rec. 56).

Ironically, the Westray Inquiry proved to be more effective at holding individuals and organizations accountable (even though it could not impose sanctions) than it was at interrogating critically the system of OHS regulation that arguably fostered the unacceptable behavior it condemned so strongly. Indeed, the thrust of its report was that the existing OHS system was fundamentally sound, if badly managed. The Westray Inquiry is not unique in this regard. For example, Susan Dodd's study of mine disaster inquiries in Nova Scotia found that mine inquiries have tended to reflect the conventional wisdom of their time (Dodd, ch. 9 this volume). Why does this happen?

As our model suggests, an important reason is that, as with other state and legal institutions, public inquiries do not stand in an external relation to society. While they are, in legal principle, both independent of government and civil society, and therefore free to challenge conventional wisdom and to recommend major system reform, they also face institutional and social constraints that shape their outcomes. Liora Salter notes in her study of public inquiries that there is a contradiction between their radical potential and their often disappointingly limited results (Salter 1990). She points to the widespread practice by governments of appointing commissioners who they see as "sound." Often, as in the case of the Westray Inquiry, they are judges who, as a group, are likely to be fairly conservative in their outlook. Moreover, Salter argues, there is an implicit understanding by the commissioners that their mandate is to produce a report that the government of the day will find acceptable and act upon. These 
appointment practices and understandings promote self-censorship and the dominance of narrow pragmatism. These tendencies are further reinforced by the appointment of researchers and other commission staff members whose views are well within the mainstream and, therefore, will be unlikely to promote critical perspectives. It is notable, for example, that the Westray Inquiry hired Ian Plummer, Ontario's former Chief Mines Inspector, who espouses a view of the IRS that minimizes the importance of worker participation and empowerment (Plummer, Strahlendorf, and Holliday 1999), to advise it on the IRS model.

The overall result is that public inquiries often function as schemes of legitimation (Ashforth 1990; Sheriff, 1983). They listen to society and speak to the state, but the vision of the common good that they advance has been filtered through a conservative understanding of proper social relations and the role of government. Legitimation, however, cannot simply be produced in a top-down manner, divorced from social reality. Rather, the inquiry process is part of a two-way conversation between state and society, albeit one that is mediated in the ways we have described. Still, the very legitimacy of the public inquiry itself derives, in part, from its public hearings at which interested groups are given the opportunity to express their views, as well as from its responsiveness to expressed concerns. Indeed, the utility of public inquiries to government is not limited to their pacification effect, but also comes from their ability to communicate to government the boundaries of what is politically acceptable in the aftermath of a disruptive event like a disaster. So, from time to time, the conservative institutional tendencies of inquiries are overcome, systems are held accountable, and more wide-sweeping recommendations are made (McEvoy 1995). The likelihood of this happening may partially be a function of the idiosyncrasies of individual commissioners, but a more important influence is the ability of victims' groups and their supporters to use the disaster to articulate a critical perspective and to translate the heightened moral authority they enjoy into popular support for system changes.

Neither was done very successfully in the aftermath of the Westray disaster. In part this was because the Westray Families and the labor movement were understandably focused on the need to hold individuals and organizations accountable (and to rebut assertions by the Premier, Donald Cameron, that the miners themselves were at fault). Of course, that was not their exclusive concern, but it was the one that tended to take precedence and for which public support was highest. Also significant was the fact that the labor movement does not have a unified position on OHS regulation. While many OHS activists were sharply critical of the current regime, a significant number of trade union leaders have embraced it, seeing it both pragmatically as the best deal they can cut politically, and as a means of providing workers with a voice in the workplace and in government, even if only as junior partners. As a result, the labor movement has tended to support modest modifications to, rather than radical critique of, the current regime. Indeed, even before the Westray Inquiry reported, the 
province's OHS law had been amended, pursuant to a series of recommendations produced by a bipartite advisory council (see below).

In sum, as in the Aberfan disaster (McLean and Johnes 2000), existing corporatist arrangements undercut the potential of the disaster to call into question the legitimacy of the OHS regime. Instead, public attention was focused on the personal and organizational failures of the mine operator and the government regulators. Under these conditions, the normal institutional tendencies of public inquiries to reflect, repair, and reproduce dominant understandings operated with little opposition.

Changing the OHS Law and Its Administration: More of the Same?-Not only does government set in motion institutions of redress like public inquiries; it provides redress directly through its own actions, whether through legislation or administrative action in response to recommendations from other bodies or on its own initiative. As we already noted, the Nova Scotia government immediately accepted all the recommendations that were within its authority to implement, including the appointment of a consultant to review the inspectors' actions. But even before the inquiry had started, in December 1992, the government initiated a review of the province's health and safety laws by the Nova Scotia Occupational Health and Safety Advisory Council (NSOHSAC), a bipartite labor-management body. They issued their consensus report, entitled Taking Responsibility (NSOHSAC 1995), a little over two years later.

The report largely endorsed the underlying principles and practices of the existing IRS. Employer and worker cooperation was expected to be the norm and the role of the government was to clarify the responsibilities of the workplace parties and support their efforts, resorting to enforcement only when necessary. The recommendations aimed to better institutionalize this system by, for example, providing better access to information and improving training for joint health and safety committee members. The issue of worker empowerment, however, was not touched upon, except in the call for greater clarity about the right of workers refusing unsafe work to be paid. Some recommendations were made in respect of enforcement, including an increase in the level of fines, but nothing was said about the level and intensity of enforcement activity. These recommendations were embodied in Bill 13, passed without dissent in 1996 by the then-Liberal government.

In the world of OHS regulation, however, administrative practice is at least as important as formal legislation. While the inspectors directly involved with Westray were terminated, it is questionable whether the division has adopted a fundamentally different approach to enforcement. Data from the annual reports of the OHS Division of the Department of Environment and Labor (Nova Scotia, various years) indicate that since 1996-97 (the first year for which systematic data are available) the annual number of inspections and stop work orders has fluctuated, but the number of orders has more than doubled (see Table 1). As 
Table 1. Nova Scotia, Department of Labor, Occupational Health and Safety Division Enforcement Activity, 1996-97-2000-04

\begin{tabular}{|c|c|c|c|c|c|c|c|c|}
\hline & $\begin{array}{c}1996- \\
97\end{array}$ & $\begin{array}{c}1997- \\
98\end{array}$ & $\begin{array}{c}1998- \\
99\end{array}$ & $\begin{array}{l}1999- \\
2000\end{array}$ & $\begin{array}{c}2000- \\
01\end{array}$ & $\begin{array}{c}2001- \\
02\end{array}$ & $\begin{array}{c}2002- \\
03\end{array}$ & $\begin{array}{c}2003 \\
04\end{array}$ \\
\hline General inspections & 1368 & 1288 & 1022 & 1563 & 1897 & 1287 & 1039 & 1460 \\
\hline Orders issued & 2684 & 3754 & 4276 & 6976 & 8610 & 5860 & 6692 & 7034 \\
\hline Stop work orders & 126 & 80 & 167 & 202 & 144 & 137 & 141 & 123 \\
\hline Prosecutions & 12 & 8 & 14 & 32 & 14 & 24 & 28 & 45 \\
\hline Work refusals & 10 & 19 & 24 & 18 & 8 & $?$ & $?$ & $?$ \\
\hline
\end{tabular}

Source: Nova Scotia, Department of Environment and Labor, OHS Division, 2003-04.

well, in the past few years there has been an increase in the number of prosecutions. These data suggest some improvement in the enforcement effort, but there is need for caution in their interpretation.

For example, the 2001 report of the Nova Scotia Auditor General raised numerous concerns about the department's enforcement practices: the department only had a little more than one-third of the businesses in the province in its tracking system; at the current rate of inspections it would take ten years to complete a full cycle of inspections; the department lacked a rigorous approach to targeting higher-risk workplaces; there was inadequate follow-up of compliance orders issued; resource limitations could result in suspected offenders not being prosecuted; finally, there were not adequate procedures in place to monitor the work activity of inspectors (NS Auditor General 2001, ch. 9). In 2003-04 the department reported that there was still an ongoing problem of achieving timely compliance with orders. As well, it reported that nearly two-thirds of prosecutions were in the construction industry. Fines for convictions are generally low; the average was less than $\$ 10,000$, while the highest was a fine of $\$ 45,000$ levied against the province's Ministry of Transport and Public Works. The largest fine against a private sector employer was $\$ 28,000$. As well, the department also reported that there is still significant non-compliance with the requirements of the IRS. Although the situation has improved in recent years, in 2003-04 one-third of employers with 20 or more employees failed to meet each of five measures of IRS compliance.

In short, while the Westray mine disaster forced the government to acknowledge that its practice of OHS regulation was deficient, the underlying assumptions that supported those practices were not seriously called into question. The few groups that raised concerns about unequal power relations in the workplace and the need to recognize that employers and workers will frequently have conflicting 
interests in OHS regulation were easily marginalized in a political climate where the labor movement not only lacks clout, but also has bought into the weak form of corporatism that OHS bipartism represents. The result is that, while personnel changes have been made, the ideology and practice of OHS regulation has largely been reconstructed in its pre-Westray form.

Criminal Law Reform-The impediments to and ultimate failure of the Westray prosecutions fueled popular support criminal law reforms that would overcome at least some of the technical difficulties that have shielded employers from being held criminally responsible for reckless conduct that caused death and injury to workers. The efforts of trade unions (particularly the USWA) and the Westray Families Group to have the Criminal Code amended received a substantial boost when the Westray inquiry accepted their submission on this point and recommended that the federal government should amend the criminal law as necessary to ensure that corporate executives and directors are held accountable for workplace safety (Richard 1997, rec. 73). As well, the fact that England and a number of jurisdictions in Australia have either enacted or are considering similar kinds of changes to their criminal laws both reflects a widespread crisis of legitimacy over the criminal law's lack of even-handedness and makes such changes appear less radical than might otherwise be the case (Glasbeek 2004a). But still, the process of reforming the criminal law was painfully slow and difficult.

Following the commission recommendation, Alexa McDonough, then the leader of the Federal NDP and herself a Nova Scotian, introduced a private member's bill in February 1998 aimed to increase the exposure of corporations, directors, and officers to criminal liability. Peter McKay, then the ProgressiveConservative Member of Parliament whose riding includes the Westray mine, also introduced a motion calling on the government to implement that recommendation. Neither the bill nor the motion proceeded in that session, but both were reintroduced in the next where, by a margin of 216 to 15, the House of Commons voted to refer McKay's motion to the Standing Committee on Justice and Human Rights. In preparation for that meeting, the Steelworkers commissioned a national poll in which $85 \%$ supported a law that "would establish fines and jail terms for corporate executives and directors found to be criminally responsible for harm or injury to employees or members of the public." Thirty-seven percent felt that the best way to prevent future Westrays was to make corporate directors criminally accountable, while another $31 \%$ supported more government inspectors (MacKinnon 2000). As well, the Steelworkers conducted an intensive four-day lobby involving members brought to Ottawa from around the country.

At the Committee, members from every political party, including from the most conservative, spoke in favor of the motion and a report issued endorsing an amendment to the Criminal Code that would ensure that "corporate executives and 
directors are held properly accountable for workplace safety" (Canada 2000). It also recommended to the Minister of Justice that legislation be brought forward in accordance with the motion and the principles underlying McDonough's private member's bill. Later that fall, the House of Commons concurred in the report, but shortly thereafter elections were called and Parliament was dissolved.

Another large Liberal majority government was returned and the private member's bill was reintroduced in February 2001. The House of Commons once again voted to send the matter to the Standing Committee, which, held hearings in 2002, and issued a report in November calling for legislation dealing with the criminal liability of corporations, officers and directors. The government accepted this recommendation and on June 12, 2003 introduced a bill (Bill 45 2003) that according to the Department of Justice (2003) "sends a clear message to employers: those who fail to provide safe workplaces will be dealt with severely through the criminal law." The bill passed and received Royal Assent on November 7, 2003. It came into force on 31 March 2004, nearly 12 years after the disaster. ${ }^{12}$

The two most pertinent changes made by the Westray Bill are that it establishes a new set of legal duties in the Criminal Code and that it makes it easier to hold an organization responsible for the acts of its senior officials. The new s. 217.1 provides:

Every one who undertakes, or has authority, to direct how another person does work or performs a task is under a legal duty to take reasonable steps to prevent bodily harm to that person, or any other person, arising from that work or harm.

The effect of the section is to impose individual criminal responsibility quite broadly. Anyone with authority to direct work, not just managerial employees, is under a duty to take reasonable steps to prevent harm. This could include, for example, the lowest level supervisory employees, a matter that concerns unions based on their experience with provincial health and safety prosecutions of co-workers, perhaps as a means of demonstrating the regulators' neutrality when also charging employers. As well, the law will impose liability for harm done to people outside the workplace, a responsibility that is not covered by most provincial health and safety laws (Nova Scotia is an exception). To successfully prosecute an individual under this section, it will not be enough to establish a breach of the relevant provincial health and safety law subject to the defense of due diligence; rather, it will be necessary to prove beyond a reasonable doubt that the individual breached her or his s. 217.1 duty recklessly or with intent.

To get at employing organizations, the Code was amended to make them parties to offences in a broader range of circumstances than in the past. First, the law does not just apply to corporations, but to organizations, including corporations, partnerships, and trade unions. Second, under the pre-existing law, 
corporations could only be held responsible for criminal conduct committed by a directing mind with policy responsibility. Under Bill C-45 organizational liability has been broadened to include criminal conduct committed at an operational level. Third, organizational responsibility has been extended deeper into the organization. In the past, corporations were only parties if criminality was found at its highest levels. Under the current law, it can be held criminally responsible if one of its representatives (which could include employees, agents, and contractors as well as directors and partners) is a party to an offense, and if a senior officer responsible for a relevant aspect of the organization's activities "departs markedly from the standard of care that, in the circumstances, could reasonably be expected to prevent a representative of the organization from being a party."13 Thus, under the new law organizations are responsible not only for monitoring the activities of their own officers and employees, but for their agents and contractors, and corporate directors cannot insulate the organization from liability by sloughing off responsibility to senior operating officials lower in the hierarchy. Finally, the new law addresses the problem of diffusion of responsibility within the organization by allowing the prosecution to prove that senior officers collectively departed markedly from the standard of care expected of them. However, it is important to note that it will not be sufficient to show that the senior officers were negligent in their oversight. The crown will have to prove criminal recklessness to establish a marked departure from the standard of care. ${ }^{14}$

It is too early to tell whether the Westray Bill will bring the criminal law more fully into OHS regime, by making it an effective weapon in the arsenal of OHS regulators and law enforcement officials. The first and, so far, only charge under Bill C-45 is against an Ontario man supervising a trench excavation performed without proper shoring. The walls collapsed and a worker was killed (Keith 2004). The charge has since been dropped. For those who hoped Bill C-45 would be used to impose criminal sanctions on corporations, this is an inauspicious beginning. Prosecutions aside, the immediate impact of the passage of Bill C-45 has been to generate business for professional risk managers (Fraser 2004; Keith 2004; McGillivray 2004) and, undoubtedly, large employers will take some measures to reduce their exposure. While this could include instituting better health and safety measures in the workplace, they may also adopt legal strategies, such as invoking their right to counsel and their right to remain silent in the aftermath of a workplace death or serious injury, that do nothing to reduce worker risk exposure. In the longer term, the impact will depend, in part, on the extent to which the amendments overcome the technical difficulties crown prosecutors faced in the past. In turn, this will depend on how the courts interpret a number of ambiguous terms in the law. The more important determinant, however, will be the extent to which crown prosecutors attempt to use the law. This brings us back to the sociological analysis discussed earlier. As long as the assumption is made that the workplace is a realm of voluntarism in which respectable employers are engaged in the respectable pursuit of profit, then it will 
remain difficult to convince enforcement officials to resort to criminal prosecutions. Indeed, recall that presently they rarely prosecute for violations of provincial health and safety laws. However, the enactment of this legislation, and the efforts in other jurisdictions to make employers criminally responsible for workplace deaths and injuries show that this assumption is being challenged. Westray has become a potent cultural and political symbol of unpunished employer criminality and the need for legal, institutional and, perhaps ultimately, social change to redress this situation.

\section{CONCLUSION}

The Westray disaster disrupted the pre-existing OHS regime that had, in effect, made private the troubles experienced by the miners and their families. It gave them and their supporters a greater public voice and opportunities to mobilize institutions of redress in pursuit of accountability for the loss of 26 lives and reform to prevent future disasters. But in the end, they met with limited success in achieving their objectives.

Monetary compensation was the least problematic because the province's workers' compensation system makes the payment of survivors' benefits a routine matter, not requiring any assignment of fault. But as a result, the workers' compensation system did not address the demands for individual, organizational, and systemic accountability. Tort law provides a mechanism for holding individuals and organizations accountable, but in Canada the statutory bar in workers' compensation statutes has virtually eliminated this form of redress, even in the aftermath of a disaster caused by serious wrongdoing. The strongest form of public accountability is through the criminal law, but though a combination of bungling, lack of government support, and technical obstacles, the Westray prosecution failed miserably. However, public outrage over employers getting away with criminal disregard for the lives of their workers, in conjunction with a broader crisis of corporate legitimacy fueled by recent scandals, created a political environment in which politicians of all political stripes felt the need to demonstrate their commitment to equality before the law, by removing at least some of the technical barriers to the successful prosecution of individuals and their employing organizations when they grossly neglect their duty to insure that work is performed safely. But in the long run, the success of the Westray Bill will depend on whether the underlying assumptions about the consensual nature of work relations that have informed health and safety regulation since the nineteenth century are changed. Ironically, the Richard commission of inquiry, which provided much needed support for criminal law reform, endorsed the very assumptions that have undermined all previous efforts to strengthen the enforcement of health and safety laws, including the incorporation of the criminal law into the OHS regime.

Thus, while the legacy of Westray remains uncertain in terms of its impact on the OHS regime, it continues to be a potent reminder of the dangers that workers 
face in a world in which there is systemic pressure on employers to maximize profits, even if that means putting production ahead of safety, and on governments to provide business-friendly regulatory climates.

\section{ENDNOTES}

1. Interview with Robert Wells, CUPE Health and Safety Representative, 11 November 2000.

2. Twenty days after the explosion the surviving miners voted in favor of the union.

3. There may also be economic losses to persons who do not suffer injury. In the case of Westray, surviving employees were laid off because of the mine's closure. The Labor Standards Board, a provincial tribunal, held that 117 miners were entitled to 12 weeks of severance pay. However, because the employer is bankrupt, the employees, who turned to Nova Scotia government for payment, were promised that they will be paid out of the proceeds of the sale of the remaining company assets.

4. There was a problem with compensation for at least one Westray miner who suffered psychological trauma arising out of his experiences in the mine rescue and recovery operations, but he recently won an appeal that awarded him $\$ 101,000$ in back payments and a monthly pension of $\$ 675$ (Naiberg 2004, pp. 20-21).

5. Quite independently of the Westray explosion, employers were already pressing the government to amend the workers' compensation legislation to address their concerns about tising costs and unfunded liabilities. Amendments enacted in 1995 responded to the employers' cost-cutting agenda, but did not adversely affect the Westray families. On the general pattern of North American workers' compensation "reforms," see McCluskey (1998).

6. Workers' compensation boards in Canada have increasingly asserted that prevention is an important part of their mandate and have pursued this goal through education and the use of economic incentives, principally experience rating. This is not the place to engage with the literature on the efficacy of experience rating except to note that it also creates incentives to engage in claims management. Claims management was pursued with a vengeance at the Westray mine. Indeed, Curragh was awarded a prestigious safety award just prior to the explosion on the basis of its fraudulently low claims experience. The award, which had been accepted by one of the miners killed in the explosion, was subsequently withdrawn (Comish 1993).

7. Part of the reason for this difference is that workers' compensation in the United States is usually less generous than in Canada and involves lawyers to a far greater extent.

8. For a somewhat longer discussion with fuller references, see Tucker (1995b).

9. The dissenting judges would have refused to order a new trial because the conduct of the Crown had brought the administration of justice into disrepute by its failures to disclose evidence and its attempts to cover this up and mislead the court.

10. It is still far more common for employers to be prosecuted under regulatory statutes, but these do not have the same normative purchase as criminal prosecutions.

11. Clifford Frame and Marvin Pelley, two senior Curragh executives, fiercely resisted efforts to subpoena them. Eventually, the commission decided to issue its report without waiting for their testimony. 
12. An Act to amend the Criminal Code (criminal liability of organizations), S.C. 2003, c. 21 .

13. S. $22.1(\mathrm{~b})$.

14. For a fuller discussion of the Criminal Code amendments and a critical assessment, see Archibald, Jull, and Roach (2004) and Glasbeek (2004b).

\section{REFERENCES}

Archibald, T., Jull, K., and Roach, K. (2004) The Changed Face of Corporate Criminal Liability. Criminal Law Quarterly, 48: 367-396.

Ashforth, A. (1990) Reckoning Schemes of Legitimation: On Commissions of Inquiry as Power/Knowledge Forms. Journal of Historical Sociology, 3: 1-22.

Atiyah, P. S. (1997) The Damages Lottery. Oxford: Hart.

Bale, A. (1989) America's First Compensation Crisis: Conflict over the Value and Meaning of Workplace Injuries under the Employers' Liability System. In D. Rosner and G. Markowitz (eds.), Dying for Work (pp. 34-52). Bloomington: Indiana University Press.

Bill C-45. (2003) An Act to amend the Criminal Code (criminal liability of organizations). House of Commons of Canada, Second Session, Thirty-seventh Parliament. (Now S.C. 2003 , c. 21$)$.

Bell v. Canada (Attorney General) (2001), 204 D.L.R. (4th) 486 (NSSC), aff'd. (2002), 208 D.L.R. (4th) 654 (N.S.C.A.), leave to appeal denied [2002] S.C.C.A. No. 135, online QL.

Benson, M. L. (2001) Prosecuting Corporate Crime: Problems and Constraints. In N. Shover and J. P. Wright (eds.), Crimes of Privilege (pp. 381-391). New York: Oxford.

Brooks, P. (2002) Westray Appeal Rejected. Halifax Herald. 16 August 2002.

Brym, R. J., and Sacouman, R. J. (eds.). (1979) Underdevelopment and Social Movements in Atlantic Canada. Toronto: New Hogtown Press.

Canada. (2000) House of Commons. Standing Committee on Justice and Human Rights. Fifth Report (6 June).

Calgary Herald (18 January 1943) Nasdegg Mine is Fined $\$ 5,000$.

Chambliss, W., and Seidman, B. (1971) Law, Order and Power. London: Addison-Wesley.

Coffee, J. Jr. (1981) "No Soul to Damn: No Body to Kick": An Unscandalized Inquiry into the Problem of Corporate Punishment. Michigan Law Review, 79: 386-459.

COHSN (8 Feb. 1993) NS WCB to pay Westray survivors about $\$ 15$ million in pensions, one-time costs.

Comish, S. (1993) The Westray Tragedy: A Miner's Story. Halifax: Fernwood.

Cooke, D. L. (2003) A System Dynamics Analysis of the Westray Mine Disaster. System Dynamics Review, 19: 139-166.

Department of Justice (2003) New Measures to Address Capital Markets Fraud, Promote Workplace Safety and Modernize the Laws Regarding Corporate Criminal Liability. Press Release, 12 June 2003, available online at http://canada.justice.gc.ca/en/news/sp/2003/doc_30930.html.

Dewees, D., Duff, D., and Trebilcock, M. (1996) Exploring the Domain of Accident Law. New York: Oxford University Press.

Dodd, S. (1998) Unsettled Accounts after Westray. In C. McCormick (1999a). pp. 218-249. 
Dodd, S. (2001) The Writing of the Westray Story: An Discursive Analysis of the Aftermath of the Westray Coal Mine Explosion. Ph.D. Dissertation. York University.

Earle, M. J. (ed.). (1989) Workers and the State in Twentieth Century Nova Scotia. Fredericton: Acadiensis Press.

Feldthusen, B. (2000) Punitive Damages: Hard Choices and High Stakes. In J. M. Flaherty and K. A. Carpenter-Gunn (eds.), Personal Injury (pp. 583-624). Ottawa: Law Society of Upper Canada.

Fraser, J. L. (2004, May) Legislating Safety-A Contentious Claim. CMA Management, $78(3): 30-32$.

Geis, G., and DiMento J. (1995) Should We Prosecute Corporations and/or Individuals. In F. Pearce and L. Snider (eds.), Corporate Crimes: Contemporary Debates (pp. 72-86). Toronto: University of Toronto Press.

Glasbeek, H. (1984) Why Corporate Deviance Is Not Treated as a Crime-The Need to Make Profits a Dirty Word. Osgoode Hall Law Journal, 22:393-439.

Glasbeek, H. (1988) A Role for Criminal Sanctions in Occupational Health and Safety. In Meredith Memorial Lectures: New Developments in Employment Law (pp. 125-149). Cowansville, Que.: Editions Yvon Blais.

Glasbeek, H. (2004a) Crime, Health and Safety and Corporations: Meanings of the Failed Crimes (Workplace Deaths and Serious Injuries) Bill. University of Melbourne, Faculty of Law Legal Studies Research Paper No. 62, Online at http://papers.ssrn.com/sol2/papers.cfm?abstract_id=521662.

Glasbeek, H. (2004b) More Criminalization in Canada: More of the Same? Paper presented at the Industrial and Corporate Manslaughter Seminar, Flinders Law School and GREWC, University of South Australia, Adelaide (March 12).

Glasbeek, H., and Tucker, E. (1993) Death by Consensus: The Westray Story. New Solutions, 3(4): 14-41.

Halifax Daily News (7 December 1997) Westray Exposed Governments' Shortcomings, p. 2.

Hopkins, A. (1989) Crime Without Punishment: The Appin Mine Disaster. In P. Grabosky and A. Sutton (eds.), Stains on a White Collar (pp. 160-174). Annandale, NSW: Federation Press.

Hyatt, D., and Law, D. K. (2000) Should Work-Injury Compensation Continue to Imbibe at the Tort Bar? In M. Gunderson and D. Hyatt (eds.), Workers' Compensation: Foundations for Reform (pp. 327-360). Toronto: University of Toronto Press.

Ison, T. G. (1967) The Forensic Lottery. London: Staples.

Jobb, D. (1994) Calculated Greed: Greed, Politics and the Westray Tragedy. Halifax: Nimbus.

Jobb, D. (1999) Legal Disaster: Westray and the Justice System. In C. McCormick (ed.), The Westray Chronicles (pp. 163-182). Halifax: Fernwood.

Keith, N. (2004) Letting Loose on Supervisors. OHS Canada October/November: 54.

King, A. (1998) The Price of Coal. Our Times, May/June: 37-40.

MacKinnon, M. (2000) Canadians Want Executives to Pay for Fatal Mistakes in Workplace. Globe and Mail, (6 June), A2.

McCluskey, M. T. (1998) The Illusion of Efficiency in Workers' Compensation Reform. Rutgers Law Review, 50: 657-941.

McCormick, C. (ed.). (1999a) The Westray Chronicles. Halifax: Fernwood.

McCormick, C. (1999b) Preface to Disaster. In C. McCormick (ed.). (1999a). 12-39. 
McEvoy, A. F. (1995) The Triangle Shirtwaist Factory Fire of 1911: Social Change, Industrial Accidents, and the Evolution of Common-Sense Causality. Law \& Social Inquiry, 20: 621-651.

McGillivray, G. (2004, March) The Dawn of Corporate Responsibility. Canadian Underwriter, 71(3): 38-43.

McLean, I., and Johnes, M. (2000) Aberfan[:] Government and Disasters. Cardiff: Welsh Academic Press.

McMullan, J., and Hinze, S. (1999) Westray: The Press, Ideology, and Corporate Crime. In C. McCormick (ed.). (1999a).

Mills, C. W. (1959) The Sociological Imagination. New York: Oxford University Press.

Naiberg, D. (2004) Miner Wins Benefits Decade After Westray. OHS Canada, (April/ June): $20-21$.

Nichols, T. (1999) The Sociology of Industrial Injury. London: Mansell.

Nova Scotia (1985) Occupational Health and Safety Act, S.N.S. 1985, c. 3.

Nova Scotia (1997) Westray [:] A Plan of Action.

Nova Scotia (various years) Department of Environment and Labor, OHS Division, Annual Report.

NS Auditor General (2001) Annual Report, 2001.

NSOHSAC (1995) Taking Responsibility. Halifax: NSOHSAC.

Pasiechnykv. Saskatchewan (Workers ' Compensation Board) (1997) [1997] 2 S.C.R. 890.

Pearce, F. (1976) Crimes of the Powerful. London: Pluto.

Pearce F., and Snider, L. (eds.). (1995) Corporate Crime: Contemporary Debates. Toronto: University of Toronto Press.

Pearce F., and Tombs, S. (1999) Toxic Capitalism: Corporate Crime and the Chemical Industry. Toronto: Canadian Scholars' Press.

Phillips v. Nova Scotia (Commission of Inquiry) (1993) 100 D.L.R. 79 (NSCA).

Phillips v. Nova Scotia (Commission of Inquiry) (1995) [1995] 2 S.C.R. 97.

Plummer I., Strahlendorf, P. S., and Holliday, M. G. (1999) The Internal Responsibility System in Ontario Mines (Interim Report \#1: Description of the IRS).

R. v. Curragh Inc. (1993) 124 N.S.R. (2d) 59 (Prov. Ct.).

R. v. Curragh Inc. (1994) 125 N.S.R. (2d) 185 (Prov. Ct.).

R. v. Curragh Inc. (1995a) [1995] S.C.C.A. No. 138 (S.C.C.).

R. v. Curragh Inc. (1995b) [1995] N.S.J. No. 275. (Prov. Ct.).

R. v. Curragh Inc. (1995c) 146 N.S.R. (2d) 161 (C.A.).

R. v. Curragh Inc. (1997) [1997] 1 S.C.R. 537 (S.C.C.).

R. v. McNamara et al. (No. 1) (1981) 56 C.C.C. (2d) 193 (Ont. C.A.), 198.

Rex.v. Brazeau Collieries (1942) 3 W.W.R. 570.

Reich, M. R. (1991) Toxic Politics: Responding to Chemical Disasters. Ithaca, NY: Cornell University Press.

Reich, M. R. (1994) Toxic Politics and Victims in the Third World. In S. Jasanoff (ed.), Learning from Disaster (pp. 180-203). Philadelphia, PA: University of Pennsylvania Press.

Rees, J. V. (1988) Reforming the Workplace: A Study of Self-Regulation in Occupational Safety. Philadelphia: University of Pennsylvania Press.

Renn, O. (1992) The Social Arena Concept of Risk Debates. In S. Krimsky and D. Golding (eds.), Social Theories of Risk (pp. 179-196). Westport, CT: Praeger. 
Richard, K. P. (1997) The Westray Story[:] A Predictable Path to Disaster. Report of the Westray Mine Public Inquiry. Halifax.

Richards, T. (1998) Public Relations and the Westray Mine Explosion. In C. McCormick (1998). pp. 136-162.

Roach, K. (1995) Canadian Public Inquiries and Accountability. In P. Stenning (ed.), Accountability for Criminal Justice (pp. 268-293). Toronto: University of Toronto Press.

Salter, L. (1990) The Two Contradictions in Public Inquiries. In A. P. Ross et al. (eds.), Commissions of Inquiry (pp. 173-195). Toronto: Carswell.

Sheriff, P. E. (1983) State Theory, Social Science, and Government Commissions. American Behavioral Scientist, 26: 669-680.

Shrivastava, P. (1987) Bhopal: Anatomy of a Crisis. Cambridge, MA: Ballinger.

Slapper, G. (1993) Corporate Manslaughter: An Examination of the Determinants of Prosecutorial Policy. Social and Legal Studies, 2: 423-443.

Slapper, G. (1999) Blood in the Bank: Social and Legal Aspects of Death at Work. Aldershot: Ashgate.

Taylor, I., Walton, P., and Young, J. (eds.). (1973) Critical Criminology. London: Routledge \& Kegan Paul.

Tombs, S. (1995) Corporate Crimes and New Organizational Forms. In F. Pearce and L. Snider (eds.). (pp. 132-146).

Tucker, E. (1990) Administering Danger in the Workplace: The Law and Politics of Occupational Health and Safety Regulation in Ontario. Toronto: University of Toronto Press.

Tucker, E. (1995a) And Defeat Goes On: An Assessment of Third Wave Health and Safety Regulation. In F. Pearce and L. Snider (eds.). (1995). pp. 245-267.

Tucker, E. (1995b) The Westray Mine Disaster and its Aftermath: The Politics of Causation. Canadian Journal of Law and Society, 10: 91-123.

Tucker, E. (1999) The Road from Westray: A Predictable Path to Disaster? Acadiensis, 28: 132-139.

Wells, C. (1995) Negotiating Tragedy: Law and Disasters. London: Sweet \& Maxwell.

Whiten v. Pilot Insurance [2002] 1 S.C.R 595. 